Ciencias Marinas (2001), 27(2): 289-309

http://dx.doi.org/10.7773/cm.v27i2.456

\title{
DEGREE OF TRACE METAL PYRITIZATION IN SEDIMENTS FROM THE PACIFIC COAST OF BAJA CALIFORNIA, MEXICO
}

\section{GRADO DE PIRITIZACIÓN DE METALES TRAZA EN SEDIMENTOS DE LA COSTA DEL PACÍFICO DE BAJA CALIFORNIA, MÉXICO}

\author{
Carmen Nava-López ${ }^{1,2}$ \\ Miguel Angel Huerta-Díaz ${ }^{2 *}$ \\ ${ }^{1}$ Facultad de Ciencias Marinas \\ ${ }^{2}$ Instituto de Investigaciones Oceanológicas \\ Universidad Autónoma de Baja California \\ Apartado postal 453 \\ Ensenada, C.P. 22800, Baja California, México \\ * E-mail: mhuerta@faro.ens.uabc.mx
}

Recibido en agosto de 2000; aceptado en marzo de 2001

\begin{abstract}
We analyzed sediments from a core collected on the Pacific coast of Baja California, $45 \mathrm{~km}$ off the city of Tijuana and at $1257 \mathrm{~m}$ water depth $\left(32^{\circ} 29.5^{\prime} \mathrm{N}, 117^{\circ} 28.3^{\prime} \mathrm{W}\right)$, for trace metal content in two operationally-defined fractions, $\mathrm{HCl}$ and pyrite. Our results indicate a transference of $\mathrm{Cu}>\mathrm{Ni}>\mathrm{Zn}>>$ $\mathrm{Hg}$ and $\mathrm{Ag}$ from the $\mathrm{HCl}$ to the pyrite fraction. Sediments have degrees of pyritization (DOP) that averaged $7.2 \pm 4.9 \%$, with a maximum value of $18.5 \%$. Average degrees of trace metal pyritization (DTMP) ranged from $6.2 \pm 2.1 \%$ to $83 \pm 18 \%$ for $\mathrm{Mn}$ and $\mathrm{Hg}$, respectively, although maximum values for some metals were close to $100 \%$. This transference is apparently a function of the solubility products of metal sulfides and the relative abundances of metals in the $\mathrm{HCl}$ fraction, as suggested by the significant correlation $(p<0.001)$ observed between these two parameters and the DTMP of a number of trace metals. A similar correlation was obtained from published data of two cores collected in the Gulf of Mexico.
\end{abstract}

Key words: trace metals, pyrite, sediment, degree of trace metal pyritization, Baja California.

\section{RESUMEN}

Se analizaron sedimentos de un núcleo recolectado en la costa del Pacífico de Baja California, $\sim 45 \mathrm{~km}$ de la costa de la ciudad de Tijuana y a $1257 \mathrm{~m}$ de profundidad del agua $\left(32^{\circ} 29.5^{\prime} \mathrm{N}, 117^{\circ} 28.3^{\prime} \mathrm{W}\right)$, para determinar su contenido de metales traza en dos fracciones operacionalmente definidas, $\mathrm{HCl}$ y pirita. Los resultados indican una transferencia de $\mathrm{Cu}>\mathrm{Ni}>\mathrm{Zn} \gg \mathrm{Hg}$ y Ag de la fracción $\mathrm{HCl}$ a la fase pirítica. Los grados de piritización (DOP) en los sedimentos promediaron $7.2 \pm 4.9 \%$, con un valor máximo de $18.5 \%$. Los valores promedio de los grados de piritización de metales traza (DTMP) abarcaron el intervalo de $6.2 \pm 2.1 \%$ a $83 \pm 18 \%$ para $\mathrm{Mn}$ y $\mathrm{Hg}$, respectivamente, aunque los valores máximos para algunos metales estuvieron cercanos al $100 \%$. Esta transferencia aparentemente es función de los productos de 
Ciencias Marinas, Vol. 27, No. 2, 2001

solubilidad de los sulfuros metálicos y de la abundancia relativa de metales en la fracción $\mathrm{HCl}$, como sugiere la correlación significativa $(p<0.001)$ observada entre estos dos parámetros y los DTMP de varios metales. Una correlación similar se obtuvo a partir de datos publicados en la literatura de dos núcleos recolectados en el Golfo de México.

Palabras clave: metales traza, pirita, sedimento, grado de piritización de metal traza, Baja California.

\section{INTRODUCTION}

Knowledge of the distribution of trace elements among major geochemical fractions of marine sediments is important since this association will determine whether metals will be preserved in the sediments or recycled back into the water column. Hence, information on this subject has important implications for studies on biogeochemical cycles and residence time of trace metals in the marine environment.

Pyrite is one of the most important authigenic minerals found in anoxic-sulfidic marine sediments (Berner, 1981) and is an important sink for a number of trace metals for Gulf of Mexico sediments (Huerta-Díaz and Morse, 1992). However, little is known about the degree of metal association with sedimentary pyrite along the Pacific coast of North America. Although there are a considerable number of published studies on sedimentary trace metal concentrations in this region (Chow et al., 1973; Bruland et al., 1974; Bertine and Goldberg, 1977; Huh et al., 1992; Morford and Emerson, 1999; Schiff, 2000), little is known about their degree of association with pyrite, since analyses in these studies included only total trace metal concentrations. Whereas total trace metal concentrations can sometimes provide meaningful information concerning background, enrichment and depletion of trace elements in aquatic sediments, they give very limited information concerning their distributions in the different mineral phases in sediments (see, for example, François, 1988). However, depending on which mineral phase they are associated with, trace metals in

\section{INTRODUCCIÓN}

El conocimiento de la distribución de los elementos traza entre las principales fracciones geoquímicas de sedimentos marinos es importante debido a que esta asociación determinará si los metales se preservarán en los sedimentos o serán reciclados de vuelta a la columna de agua. Por tanto, la información en este ámbito tiene importantes aplicaciones para el estudio de los ciclos biogeoquímicos y los tiempos de residencia de los metales traza en el medio marino.

La pirita es uno de los minerales autigénicos más importantes encontrados en los sedimentos marinos anóxico-sulfídico (Berner, 1981) y constituye un sumidero importante para un buen número de metales traza en los sedimentos del Golfo de México (Huerta-Díaz y Morse, 1992). Sin embargo, poco se sabe acerca del grado de asociación de los metales con la pirita sedimentaria a lo largo de la costa del Pacífico de Norteamérica. Aunque existe un considerable número de estudios publicados sobre las concentraciones de metales traza en esta región (Chow et al., 1973; Bruland et al., 1974; Bertine y Goldberg, 1977; Huh et al., 1992; Morford y Emerson, 1999; Schiff, 2000), se sabe poco acerca del grado de asociación con la pirita, pues los análisis en esos estudios incluyen sólo las concentraciones totales de metales traza. Mientras que las concentraciones totales de metales traza algunas veces pueden proveer información significativa en relación con los antecedentes, el enriquecimiento y el agotamiento de metales traza en sedimentos acuáticos, éstas dan información muy limitada 
sediments can possess different degrees of reactivity and lability toward their incorporation, formation or dissolution of new minerals, or toward their incorporation into living matter. Only a few studies have been made on the distribution of metals in operationally-defined fractions of sediments along the coasts of Baja California and California (Villaescusa-Celaya et al., 1997, 2000); however, these studies involved superficial, oxic sediments close to the sediment-water interface, where pyrite is not formed diagenetically (Berner, 1981).

The main objective of this study is to evaluate the importance of this mineral phase as a reservoir of trace metals in sediments fromthe Pacific coast of Baja California. Here, we present results from a sediment core collected approximately $45 \mathrm{~km}$ off Tijuana, Baja California, Mexico (fig. 1). We analyzed 24 samples for trace metals associated with two operationally-defined fractions, namely $\mathrm{HCl}$ and pyrite. These two fractions, used in combination with each other, provide information concerning the degree of association of trace metals with pyrite.

\section{MATERIALS AND METHODS}

Sediment samples were collected using a stainless steel box corer $(40 \times 40 \mathrm{~cm}$ sampling area and $60 \mathrm{~cm}$ in height) at $1257 \mathrm{~m}$ water depth $\left(32^{\circ} 29.5^{\prime} \mathrm{N}, 117^{\circ} 28.3^{\prime} \mathrm{W}\right.$; fig 1$)$, on board the oceanographic ship Francisco de Ulloa, as part of the scientific cruise METOX-02 (December 1996). Two sub-cores were collected simultaneously from the center of the box corer, using polycarbonate core liners (7.2 $\mathrm{cm}$ interior diameter, $60 \mathrm{~cm}$ in length). The two cores collected (25 and $28 \mathrm{~cm}$ in length) were immediately sliced into individual centimeter sections with a plastic spatula and each section transferred to $50-\mathrm{mL}$ centrifuge polypropylene tubes, and stored at $-20^{\circ} \mathrm{C}$ for further laboratory analysis onshore. No $\mathrm{H}_{2} \mathrm{~S}$ en relación con su distribución en las diferentes fases minerales de los sedimentos (ver, por ejemplo, François, 1988). Sin embargo, dependiendo de la fase mineral con la que se encuentren asociados, los metales traza en los sedimentos pueden poseer diferentes grados de reactividad y labilidad hacia su incorporación, formación o disolución de nuevos minerales, o hacia su incorporación en la materia viva. Se han hecho pocos estudios sobre la distribución de metales en las fracciones operacionalmente definidas de los sedimentos a lo largo de las costas de Baja California y California (Villaescusa-Celaya et al., 1997, 2000); sin embargo, estos estudios involucraron sedimentos óxicos superficiales cercanos a la interfase sedimento-agua, donde la pirita no se forma diagenéticamente (Berner, 1981).

El principal objetivo de este estudio es evaluar la importancia de esta fase mineral como un reservorio de metales traza en los sedimentos de la costa del Pacífico de Baja California. Aquí se presentan los resultados de un núcleo de sedimentos recolectados alrededor de $45 \mathrm{~km}$ de las costas de Tijuana, Baja California, México (fig. 1). Se analizaron 24 muestras de metales traza asociadas con dos fracciones definidas operacionalmente, a saber, $\mathrm{HCl}$ y pirita. Estas dos fracciones, utilizadas en combinación una con la otra, proveen información respecto al grado de asociación de los metales traza con la pirita.

\section{MATERIALES Y MÉTODOS}

Se recolectaron muestras de sedimentos usando un nucleador de caja de acero inoxidable (de $40 \times 40 \mathrm{~cm}$ de área de muestreo y $60 \mathrm{~cm}$ de altura) a una profundidad de agua de $1257 \mathrm{~m}$ $\left(32^{\circ} 29.5^{\prime} \mathrm{N}, 117^{\circ} 28.3^{\prime} \mathrm{W}\right.$; fig. 1$)$, a bordo del barco oceanográfico Francisco de Ulloa, como parte del crucero científico METOX-02 (diciembre de 1996). Dos subnúcleos fueron recolectados simultáneamente del centro del 


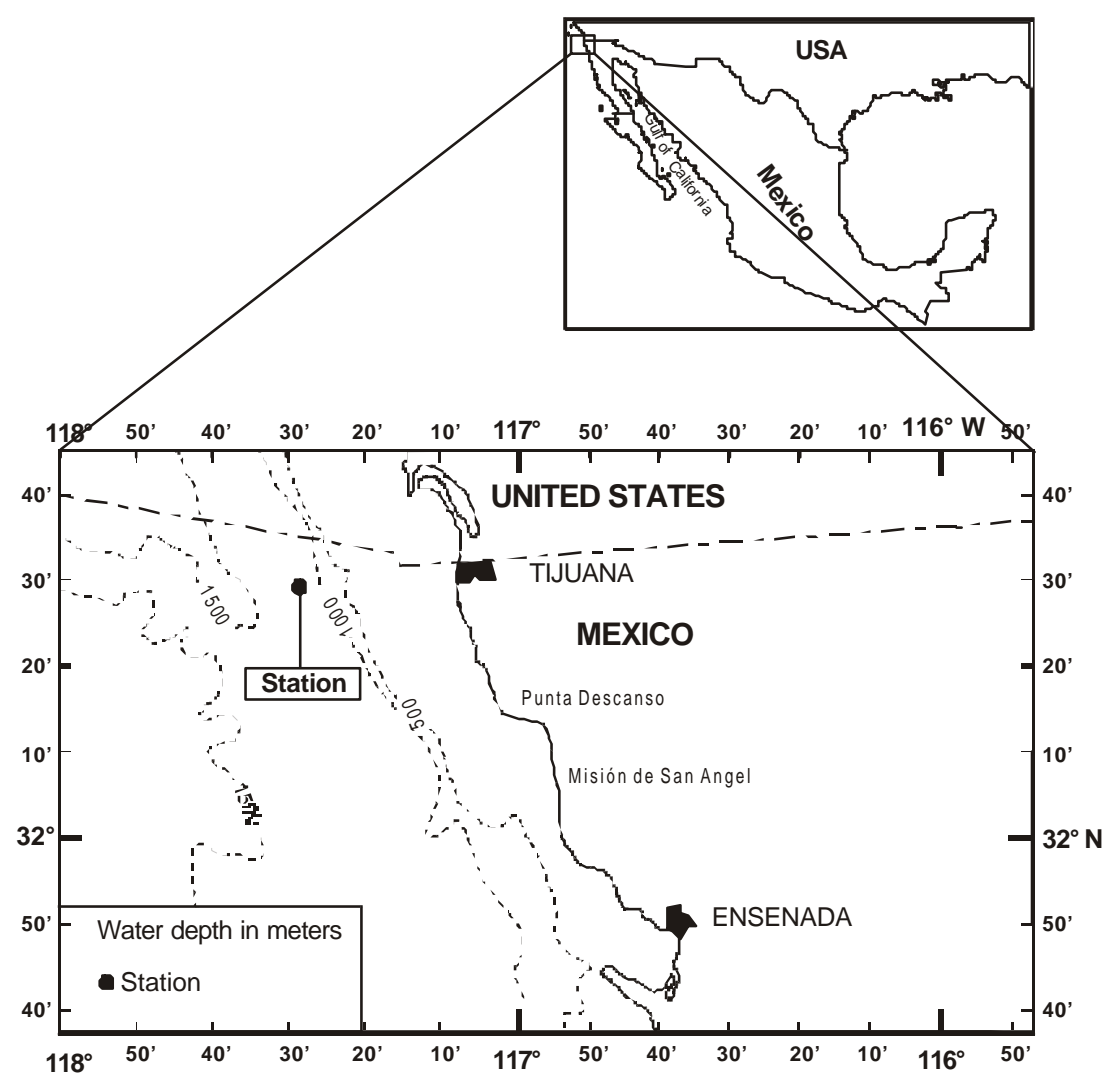

Figure 1. Location of the sampling station in the Pacific Ocean, off Tijuana, Baja California, Mexico. Figura 1. Ubicación de la estación de muestreo en el Océano Pacífico, frente a Tijuana, Baja California, México.

smell was detected during slicing the core, suggesting very low concentrations of this dissolved species in pore water. All laboratory materials were previously washed with phosphate-free soap, rinsed three times with distilled water and left 24 hours in a $5 \% \mathrm{HCl}$ solution. Next, the material was rinsed three times with deionized water Milli-Q grade and left semi-closed to dry at room temperature. Samples from the first core $(25 \mathrm{~cm}$ long) were nucleador de caja, utilizando tubos de policarbonato $(7.2 \mathrm{~cm}$ de diámetro interior, $60 \mathrm{~cm}$ de longitud). Los dos núcleos recolectados (25 y $28 \mathrm{~cm}$ de longitud) fueron rebanados inmediatamente en secciones individuales de $1 \mathrm{~cm}$ con una espátula de plástico y cada sección fue transferida a tubos de polipropileno para centrífuga de $50 \mathrm{~mL}$, y guardados a $-20^{\circ} \mathrm{C}$ para su posterior análisis en tierra. No se detectó ningún olor a $\mathrm{H}_{2} \mathrm{~S}$ durante el seccionado del 
used for all analyses, except for the determination of acid volatile sulfides (AVS), for which samples from the second core $(28 \mathrm{~cm}$ long) were used. In this work, and for all practical purposes, all metals associated with sediments will be designated as trace metals, independently of their concentration level. All reagents used were reagent grade or better. Blanks were routinely analyzed and included in each batch of samples, and all were found to be below their lower limit of detection (LLD).

Percentage by weight of water and solid for each sample was calculated by drying approximately 1-2 $\mathrm{g}$ of wet sediment in an oven at $\sim 80^{\circ} \mathrm{C}$, until a constant weight was obtained. AVS was measured with a modification of the method of Cornwell and Morse (1987), using 50-mL plastic centrifuge tubes as reaction vessels and a trapping solution prepared with $64 \mathrm{~mL}$ of a $5 \%$ zinc acetate solution $(\mathrm{m} / \mathrm{v})$ dissolved in $1.25 \%$ sodium acetate $(\mathrm{m} / \mathrm{v})$, which precipitated the $\mathrm{H}_{2} \mathrm{~S}$ evolved from the samples as $\mathrm{ZnS}$. The precipitate was later dissolved with Cline reagent (Cline, 1969), which reacts with the sulfur from the $\mathrm{ZnS}$ to produce methylene blue, whose concentration is directly proportional to the $\mathrm{H}_{2} \mathrm{~S}$ concentration. The $\mathrm{H}_{2} \mathrm{~S}$ concentration was determined colorimetrically with a spectrophotometer, UV-VIS Spectronic model Genesys 2, using a 670-nm wavelength. The calibration curve was made using standards prepared with $\mathrm{Na}_{2} \mathrm{~S} \cdot 9 \mathrm{H}_{2} \mathrm{O}$. Our calculated LLD of the method was $0.04 \mu \mathrm{M}$, equivalent to approximately 4 nmol-AVS $\mathrm{g}^{-1}$ dry sediment. The precision of the method, calculated by determining the absorbance of five replicate sulfide standards at various concentration levels, indicated that the overall method, not including any sampling errors, gave a precision of $\pm 3 \%$ at the $95 \%$ confidence level. Final AVS concentrations on a dry weight basis were calculated from the percentage by weight determined earlier. núcleo, lo que sugiere muy bajas concentraciones de esta especie disueltas en las aguas intersticiales. Todos los materiales de laboratorio fueron lavados previamente con jabón libre de fosfatos, enjuagados tres veces con agua destilada y dejados 24 horas en una solución de $\mathrm{HCl}$ al 5\%. Posteriormente, el material se enjuagó tres veces con agua desionizada grado Milli-Q y se dejó secar, semicerrado, a temperatura ambiente. Las muestras del primer núcleo $(25 \mathrm{~cm}$ de largo) se utilizaron para todoslos análisis, a excepción de la determinación de sulfuros volátiles en ácido (AVS), para la que se usaron muestras del segundo núcleo $(28 \mathrm{~cm}$ de largo). En este trabajo, y para todo fin práctico, todos los metales asociados con los sedimentos se denominarán metales traza, independientemente de su nivel de concentración. Todos los reactivos utilizados fueron de grado reactivo o superior. Los testigos fueron analizados e incluidos de manera rutinaria en cada serie de muestras y todos se encontraron por debajo del límite inferior de detección (LLD).

Se calculó a cada muestra el porcentaje de agua y sólidos en peso, secando aproximadamente 1-2 g de sedimento húmedo en un horno a $\sim 80^{\circ} \mathrm{C}$, a peso constante. Se midieron los AVS mediante una modificación del método de Cornwell y Morse (1987), utilizando tubos de plástico para centrífuga de $50 \mathrm{~mL}$ como cámaras de reacción, y una solución trampa preparada con $64 \mathrm{~mL}$ de acetato de zinc al $5 \%(\mathrm{~m} / \mathrm{v})$ disuelto en acetato de sodio al $1.25 \%(\mathrm{~m} / \mathrm{v})$, la cual precipitó el $\mathrm{H}_{2} \mathrm{~S}$ surgido de las muestras en $\mathrm{ZnS}$. El precipitado posteriormente fue disuelto con reactivo de Cline (Cline, 1969), el cual reacciona con el azufre del $\mathrm{ZnS}$ produciendo azul de metileno cuya concentración es directamente proporcional a la concentración de $\mathrm{H}_{2} \mathrm{~S}$. La concentración de $\mathrm{H}_{2} \mathrm{~S}$ se determinó por colorimetría con un espectrofotómetro UV-VIS Spectronic 
Ciencias Marinas, Vol. 27, No. 2, 2001

A chemical sequential extraction was carried out to obtain the operationally-defined fractions $\mathrm{HCl}$, silicate and pyrite (Huerta-Díaz and Morse, 1990). We used a predetermined amount of homogenized wet sediment, equivalent to $2.5 \mathrm{~g}$ dry weight, which was previously calculated from the percentage by weight of water and solid for each sample. The method consists of digesting the sediment during 16hours with $20 \mathrm{~mL}$ of $1 \mathrm{~N} \mathrm{HCl}$ to obtain the $\mathrm{HCl}$ fraction (which includes carbonates, $\mathrm{Fe}$ and Mn oxides, and AVS); two successive digestions using, each time, $30 \mathrm{~mL}$ of $10 \mathrm{M} \mathrm{HF}$ ( 1 and 16 hours, respectively) to obtain the silicate fraction (aluminosilicates, mainly clays); and finally, dissolving the resulting residue (pyrite fraction) with $10 \mathrm{~mL}$ of concentrated $\mathrm{HNO}_{3}$ during one hour. The silicate fraction was discarded since its associated trace metals are essentially non-reactive toward the formation of pyrite during early diagenesis (Huerta-Díaz and Morse, 1990).

Results from the $\mathrm{HCl}$ and pyrite fractions for $\mathrm{Fe}(\mathrm{Fe}-\mathrm{HCl}$ and $\mathrm{Fe}$-pyrite, respectively) are combined to calculate the degree of pyritization (DOP) of the sediments. This term was introduced by Berner (1970) and used to evaluate the amount of Fe present as pyrite relative to the so-called "reactive $\mathrm{Fe}$ " $(\mathrm{Fe}$-pyrite $+\mathrm{Fe}-\mathrm{HCl})$. The DOP is calculated using the following equation:

$$
\mathrm{DOP}=\left(\frac{\text { Fe-pyrite }}{\text { Fe-pyrite }+ \text { Fe-HCl }}\right) \times 100
$$

This concept was further extended to other metals by Huerta-Díaz and Morse (1990), who introduced the concept of degree of trace metal pyritization (DTMP), which can be calculated with the following equation:

$$
\text { DTMP }=\left(\frac{\text { Me-pyrite }}{\text { Me-pyrite }+ \text { Me-HCl }}\right) \times 100
$$

modelo Genesys 2, usando una longitud de onda de $670 \mathrm{~nm}$. La curva de calibración se realizó usando estándares preparados con $\mathrm{Na}_{2} \mathrm{~S} \cdot 9 \mathrm{H}_{2} \mathrm{O}$. El LLD que se calculó para este método fue $0.04 \mu \mathrm{M}$, equivalente a aproximadamente 4 nmol-AVS $\mathrm{g}^{-1}$ de sedimento seco. La precisión del método, calculada determinando la absorbancia de cinco réplicas de estándares de sulfuro a varios niveles de concentración, indicó que el método en su conjunto, sin incluir errores de muestreo, dio una precisión de $\pm 3 \%$ a un nivel de confianza del 95\%. Las concentraciones finales de AVS con base en peso seco se calcularon a partir del porcentaje en peso determinado anteriormente.

Se realizó una extracción química secuencial para obtener las fracciones definidas operacionalmente como $\mathrm{HCl}$, silicatos y pirita (Huerta-Díaz y Morse, 1990). Se utilizó una cantidad predeterminada de sedimento húmedo homogeneizado, equivalente a $2.5 \mathrm{~g}$ en peso seco, la cual se estimó previamente a partir del porcentaje de agua y sólidos para cada muestra. El método consiste en digerir el sedimento durante 16 horas con $20 \mathrm{~mL}$ de $\mathrm{HCl} 1 \mathrm{~N}$ para obtener la fracción $\mathrm{HCl}$ (que incluye carbonatos, óxidos de Fe y Mn, y AVS); dos digestiones sucesivas usando en cada una $30 \mathrm{~mL}$ de HF 10M (1 y 16 horas, respectivamente) para obtener la fracción de silicatos (aluminosilicatos, principalmente arcillas); y finalmente, el residuo resultante (fracción pirita) es disuelto con $10 \mathrm{~mL}$ de $\mathrm{HNO}_{3}$ concentrado, durante una hora. La fracción de silicatos fue desechada debido a que los metales traza asociados con ella son esencialmente no reactivos hacia la formación de pirita durante la diagénesis temprana (Huerta-Díaz y Morse, 1990).

Los resultados de las fracciones $\mathrm{HCl}$ y pirita para el $\mathrm{Fe}(\mathrm{Fe}-\mathrm{HCl}$ y $\mathrm{Fe}$-pirita, respectivamente) se combinan para calcular el grado de piritización (DOP) de los sedimentos. Este término fue introducido por Berner (1970) y utilizado para evaluar la cantidad de $\mathrm{Fe}$ 
where Me-pyrite and $\mathrm{Me}-\mathrm{HCl}$ represent the concentrations of a given metal in the pyrite and $\mathrm{HCl}$ fractions, respectively.

We measured trace metal concentrations $(\mathrm{Ag}, \mathrm{Al}, \mathrm{Cd}, \mathrm{Co}, \mathrm{Cr}, \mathrm{Cu}, \mathrm{Fe}, \mathrm{Mn}, \mathrm{Ni}, \mathrm{Pb}$ and $\mathrm{Zn}$ ) with an atomic absorption (AA) spectrophotometer, Thermo Jarrell Ash model Smith Hieftje 12 with background correction. All metals whose concentrations were below their respective flame AA LLD were determined by graphite furnace atomic absorption (Thermo Jarrell Ash model Furnace Atomizer 188). Mercury was measured by AA spectrophotometry using a cold vapor technique (Thermo Jarrell Instrumentation Laboratory model AVA440). We calculated the LLD for the $\mathrm{HCl}$ and pyrite fractions (table 1) as three times the standard deviation of the least concentrated operational standard (Bruland et al., 1979).

\section{RESULTS}

The Fe results will be presented first, because this element generally controls the distribution of trace metals in sediments due to its natural abundance and diagenetic activity. Fe-pyrite concentrations (fig. 2a) remained relatively constant at about $3 \mu \mathrm{mol} \mathrm{g}^{-1}$ during the first $7 \mathrm{~cm}$ depth and then at about $5 \mu \mathrm{mol} \mathrm{g} \mathrm{g}^{-1}$ down to $15 \mathrm{~cm}$ depth, after which their values gradually increased until a concentration of $18 \mu \mathrm{mol} \mathrm{g} \mathrm{g}^{-1}$ was reached in the deepest part of the core. $\mathrm{Fe}-\mathrm{HCl}$ concentrations (fig. 2a) remained relatively constant at around $150 \mu \mathrm{mol} \mathrm{g}^{-1}$ within the first $5 \mathrm{~cm}$, decreasing rapidly to about $90 \mu \mathrm{mol} \mathrm{g}^{-1}$ between 5 and $8 \mathrm{~cm}$, after which the values remained relatively constant downcore. The relatively constant $\mathrm{Fe}-\mathrm{HCl}$ concentrations observed from 0 to $5 \mathrm{~cm}$ suggests that the aerobic part of the sediment probably extends down to this depth, after which the concentrations start to decrease due to the reductive presente como pirita, en relación con el llamado "Fe reactivo" (Fe-pirita + $\mathrm{FeHCl}$ ). El DOP se calcula mediante la siguiente ecuación:

$$
\mathrm{DOP}=\left(\frac{\mathrm{Fe}-\text { pirita }}{\mathrm{Fe}-\text { pirita }+\mathrm{Fe}-\mathrm{HCl}}\right) \times 100
$$

Después, este concepto fue ampliado para otros metales por Huerta-Díaz y Morse (1990), quienes introdujeron el concepto de grado de piritización de metales traza (DTMP), que puede ser calculado con la siguiente ecuación:

$$
\text { DTMP }=\left(\frac{\text { Me-pirita }}{\text { Me-pirita }+ \text { Me-HCl }}\right) \times 100
$$

donde $\mathrm{Me}$-pirita y $\mathrm{Me}-\mathrm{HCl}$ representan las concentraciones de un metal dado en las fracciones pirita y $\mathrm{HCl}$, respectivamente.

$\mathrm{Se}$ midieron las concentraciones de los metales (Ag, Al, Cd, Co, Cr, Cu, Fe, Mn, Ni, $\mathrm{Pb}$ y $\mathrm{Zn}$ ) con un espectrofotómetro de absorción atómica (AA), Thermo Jarrell Ash modelo Smith Hieftje 12 con corrector de fondo. Todos los metales cuyas concentraciones estuvieron por debajo de sus LLD de AA a la flama se determinaron por absorción atómica en horno de grafito (Thermo Jarrell Ash modelo Furnace Atomizer 188). El mercurio se midió por espectrofotometría de AA usando una técnica de vapor frío (Thermo Jarrel Instrumentation Laboratory modelo AVA-440). Se calculó el LLD para las fracciones $\mathrm{HCl}$ y pirita (tabla 1) como tres veces la desviación estándar operacional del estándar menos concentrado (Bruland et al., 1979).

\section{RESULTADOS}

Primero se presentarán los resultados para el Fe ya que este elemento generalmente controla la distribución de los metales traza en los sedimentos debido a su abundancia natural y a 

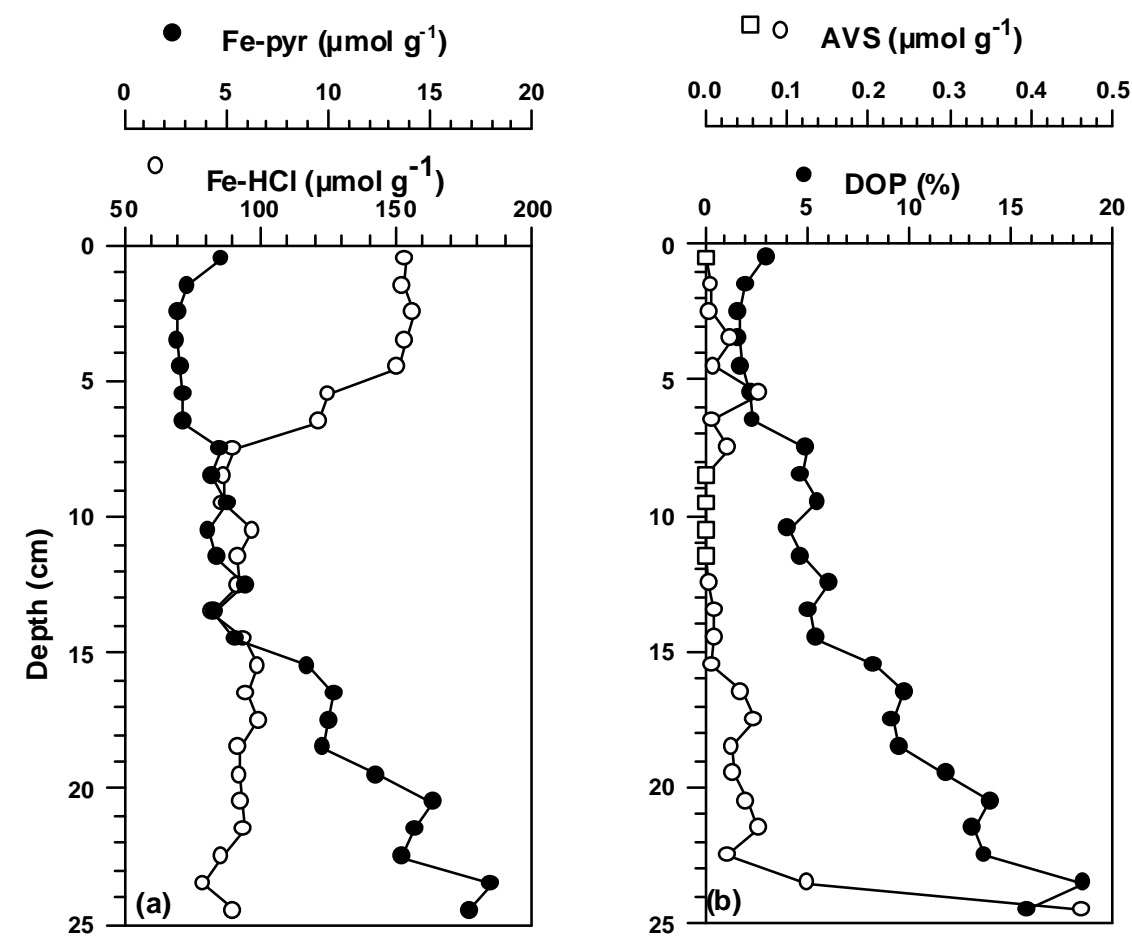

Figure 2. Concentrations of $\mathrm{Fe}$ in sediment extracted from (a) pyrite and $\mathrm{HCl}$ fractions (Fe-pyr and $\mathrm{Fe}-$ $\mathrm{HCl}$ ), and (b) concentrations of acid volatile sulfides (AVS) and degrees of pyritization (DOP). Squared symbols represent values below the lower limit of detection (LLD).

Figura 2. Concentraciones de Fe en el sedimento extraído de (a) las fracciones pirita y $\mathrm{HCl}$ (Fe-pyr y $\mathrm{Fe}-$ $\mathrm{HCl}$ ), y (b) concentraciones de sulfuros volátiles en ácido (AVS) y grados de piritización (DOP). Los símbolos cuadrados representan valores por debajo del límite inferior de detección (LLD).

dissolution of Fe oxyhydroxides. The presence of this aerobic zone may also be indirectly observed in the low and constant Fe-pyrite concentrations (probably detrital in origin) found in the first $7 \mathrm{~cm}$ depth. It can be observed in figure $2 \mathrm{a}$ that when the $\mathrm{Fe}-\mathrm{HCl}$ concentrations decrease, the corresponding Fe-pyrite concentrations increase. This behavior has already been observed in marine sediments, and indicates that $\mathrm{Fe}$ associated with the $\mathrm{HCl}$ fraction is gradually converted to pyritic $\mathrm{Fe}$ (Berner, 1970, 1984; Rickard et al., 1995). The gradual incorporation of $\mathrm{Fe}$ into the pyrite phase is also su actividad diagenética. Las concentraciones de Fe-pirita (fig. 2a) permanecieron relativamente constantes en cerca de $3 \mu \mathrm{mol} \mathrm{g}^{-1}$ durante los primeros $7 \mathrm{~cm}$ de profundidad y

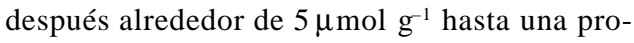
fundidad de $15 \mathrm{~cm}$, debajo de la cual sus valores aumentaron gradualmente hasta alcanzar una concentración de $18 \mu \mathrm{mol} \mathrm{g} \mathrm{g}^{-1}$ en la parte más profunda del núcleo. Las concentraciones de Fe-pirita (fig. 2a) permanecieron relativamente constantes en alrededor de $150 \mu \mathrm{mol} \mathrm{g}^{-1}$ dentro de los primeros $5 \mathrm{~cm}$, disminuyendo rápidamente hasta cerca de $90 \mu \mathrm{mol} \mathrm{g}{ }^{-1}$ entre 
Nava-López and Huerta-Díaz: Degree of trace metal pyritization in sediments

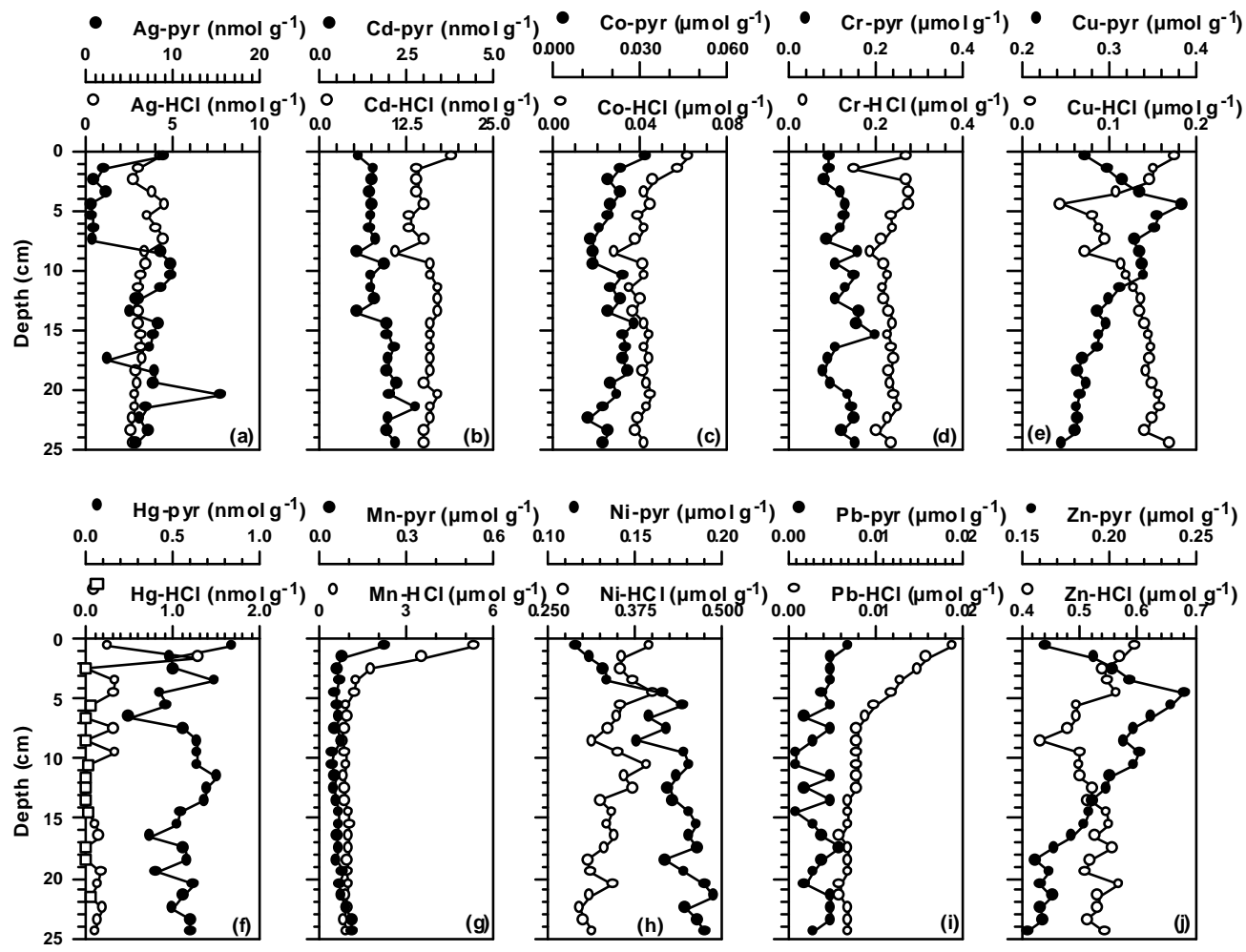

Figure 3. Concentrations of trace metals in sediment extracted from $\mathrm{HCl}$ and pyrite fractions. Squared symbols represent values below the lower limit of detection (LLD).

Figura 3. Concentraciones de metales traza en sedimento extraído de las fracciones $\mathrm{HCl}$ y pirita. Los símbolos cuadrados representan valores por debajo del límite inferior de detección (LLD).

reflected in the steady increase in DOP values below the $7 \mathrm{~cm}$ depth (fig. 2b), suggesting again that reductive dissolution of $\mathrm{Fe}$ oxyhydroxides, and transference of Fe to pyrite, starts at this depth.

Results for other trace metals associated with the $\mathrm{HCl}$ fraction (fig. 3) show enrichments close to the sediment-water interface for essentially all of the elements, except $\mathrm{Hg}, \mathrm{Cr}$ and, to a certain extent, Ag. This enrichment is probably the result of their association with Mn oxyhydroxides, since this element also displays high concentrations in the $\mathrm{HCl}$ fraction close to the sediment-water interface (fig. $3 \mathrm{~g}$ ). $\mathrm{Cd}$, Co, los 5 y $8 \mathrm{~cm}$, después de lo cual los valores permanecieron relativamente constantes hacia la parte baja del núcleo. Las concentraciones relativamente constantes de $\mathrm{Fe}-\mathrm{HCl}$ observadas de 0 a $5 \mathrm{~cm}$ sugieren que la porción aeróbica del sedimento probablemente se extiende hasta esta profundidad, después de la cual las concentraciones empiezan a disminuir debido a la disolución reductiva de los oxihidróxidos de Fe. La presencia de esta zona aeróbica puede también ser observada indirectamente en las bajas y constantes concentraciones de Fe-pirita (probablemente de origen detrítico) encontradas en los primeros $7 \mathrm{~cm}$ de profundidad. En la 
Ciencias Marinas, Vol. 27, No. 2, 2001

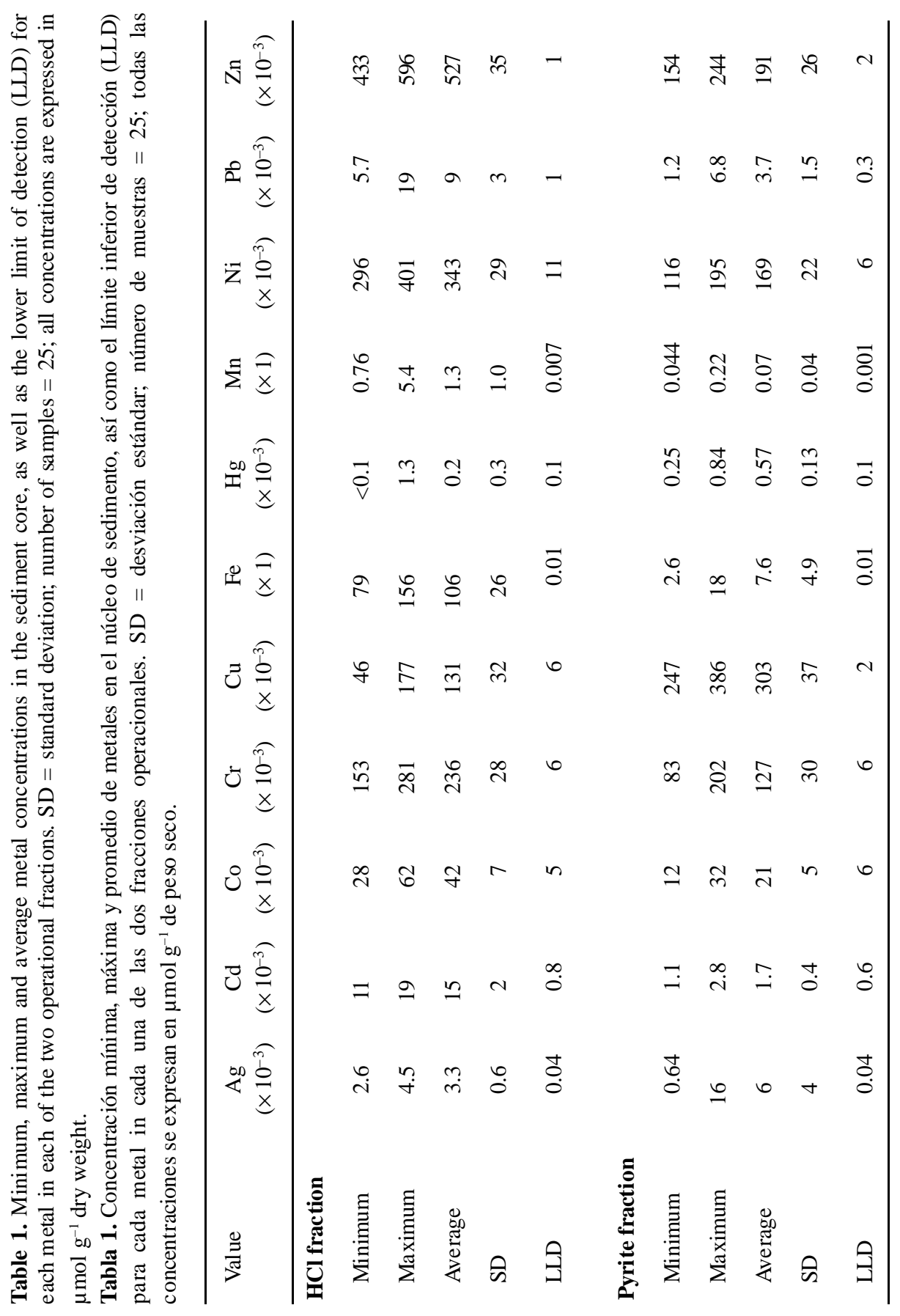


$\mathrm{Mn}, \mathrm{Pb}$ and, possibly, $\mathrm{Cr}$ have similar profile shapes in both fractions, whereas $\mathrm{Cu}, \mathrm{Ni}, \mathrm{Zn}$ and, to a certain extent, $\mathrm{Hg}$ have profiles showing mirror image shapes, i.e., when the concentration in one fraction increases, the concentration in the other fraction decreases. $\mathrm{Co}, \mathrm{Ni}, \mathrm{Pb}$ and $\mathrm{Zn}$ in the $\mathrm{HCl}$ fraction show a gradual decrease between 8 and $9 \mathrm{~cm}$, and below that depth either show constant concentrations ( $\mathrm{Co}$ and $\mathrm{Pb}$ in the $\mathrm{HCl}$ fraction) or a constant increase $(\mathrm{Cu}$ and $\mathrm{Zn}$ in the $\mathrm{HCl}$ fraction) to the end of the core. These profiles are similar to the $\mathrm{Fe}-\mathrm{HCl}$ profile (fig. 2a), which decreases in the first $8 \mathrm{~cm}$ and below that keeps approximately a constant concentration $\left(5 \mu \mathrm{mol} \mathrm{g}^{1}\right)$. The average metal concentration in the $\mathrm{HCl}$ fraction (table 1, fig. 3) followed the order $\mathrm{Fe}>\mathrm{Mn}>\mathrm{Zn}>\mathrm{Ni}>\mathrm{Cr}>$ $\mathrm{Cu}>\mathrm{Co}>\mathrm{Cd}>\mathrm{Pb}>\mathrm{Ag}>\mathrm{Hg}$, whereas for the pyrite fraction, the abundance order was $\mathrm{Fe}>\mathrm{Cu}>\mathrm{Zn}>\mathrm{Ni}>\mathrm{Cr}>\mathrm{Mn}>\mathrm{Co}>\mathrm{Ag}>$ $\mathrm{Pb}>\mathrm{Cd}>\mathrm{Hg}$. Use of $t$-tests or Mann-Whitney Rank Sum tests (if a normality test failed) gave significant differences $\varphi<0.001$ ) between each group of data, indicating the existence of real differences among the different average metal concentrations. The most abundant element in both fractions was $\mathrm{Fe}$, whereas $\mathrm{Mn}$ and $\mathrm{Cu}$ were the second most abundant elements in the $\mathrm{HCl}$ and pyrite fractions, respectively (table 1 ).

Relatively constant low values of DOP (about 2\%) were observed during the first $7 \mathrm{~cm}$ depth; they then increased gradually with depth to about $19 \%$ until the end of the core (fig. $2 b$ ). These values are low compared to DOP levels of up to $40 \%$ in some anoxic-sulfidic sediments (Huerta-Díaz and Morse, 1992). DTMP results show an increase in pyritization with depth for $\mathrm{Mn}$ and $\mathrm{Ni}$, whereas $\mathrm{Cd}$, $\mathrm{Co}$ and $\mathrm{Cr}$ maintain relatively constant DTMP values throughout the core (fig. 4). $\mathrm{Cu}$ and $\mathrm{Zn}$ showed maximum values at 5 and $9 \mathrm{~cm}$ depth, respectively, while $\mathrm{Ag}$ levels decreased during the first $5 \mathrm{~cm}$, figura $2 \mathrm{a}$ se puede observar que cuando las concentraciones de $\mathrm{Fe}-\mathrm{HCl}$ disminuyen, las concentraciones de Fe-pirita aumentan. Este comportamiento ya ha sido observado en sedimentos marinos, e indica que el Fe asociado con la fracción $\mathrm{HCl}$ se convierte gradualmente en Fe pirítico (Berner, 1970, 1984; Rickard et $a l ., 1995)$. La incorporación gradual del Fe a la fase pirítica también se refleja en el incremento constante de los valores de DOP abajo de los $7 \mathrm{~cm}$ de profundidad (fig. 2b), lo que sugiere otra vez que la disolución reductiva de los oxihidróxidos de $\mathrm{Fe}$, y la transferencia de Fe a la pirita, comienzan a esta profundidad.

Los resultados para otros metales traza asociados con la fracción $\mathrm{HCl}$ (fig. 3) muestran enriquecimientos cercanos a la interfase sedimento-agua prácticamente para todos los elementos, a excepción del $\mathrm{Hg}$, el $\mathrm{Cr}$ $\mathrm{y}$, hasta cierto punto, la Ag. Este enriquecimiento es probablemente el resultado de su asociación con los oxihidróxidos de $\mathrm{Mn}$, ya que este elemento también presenta elevadas concentraciones en la fracción $\mathrm{HCl}$ cercana a la interfase sedimento-agua (fig. $3 \mathrm{~g}$ ). $\mathrm{El} \mathrm{Cd}$, $\mathrm{Co}, \mathrm{Mn}, \mathrm{Pb}$ y, posiblemente, $\mathrm{Cr}$ tienen per- files de forma similar en ambas fracciones, mientras que el $\mathrm{Cu}, \mathrm{Ni}, \mathrm{Zn}$ y, hasta cierto punto, $\mathrm{Hg}$ tienen perfiles de imágenes en espejo, es decir, cuando su concentración aumenta en una fracción, en la otra dismi- nuye. El Co, $\mathrm{Ni}, \mathrm{Pb}$ y $\mathrm{Zn}$ en la fracción $\mathrm{HCl}$ muestran una disminución gradual entre los 8 y $9 \mathrm{~cm}$ y debajo de esta profundidad, o bien presentan concentraciones constantes ( $\mathrm{Co}$ y $\mathrm{Pb}$ de la fracción $\mathrm{HCl}$ ), o bien aumen- $\tan$ de manera constante hacia el final del núcleo $(\mathrm{Cu}$ y $\mathrm{Zn}$ en la fracción $\mathrm{HCl})$. Estos perfiles tienen similitud con el perfil Fe$\mathrm{HCl}$ (fig. 2a), el cual disminuye en los primeros $8 \mathrm{~cm}$ y más abajo mantiene una concentración más o menos constante $\left(5 \mu \mathrm{mol} \mathrm{g}^{-1}\right)$. La concentración promedio de los metales en la fracción $\mathrm{HCl}$ (tabla 1, fig. 3) siguió el orden $\mathrm{Fe}>\mathrm{Mn}>\mathrm{Zn}>\mathrm{Ni}>\mathrm{Cr}>\mathrm{Cu}>\mathrm{Co}>\mathrm{Cd}>$ 
Ciencias Marinas, Vol. 27, No. 2, 2001

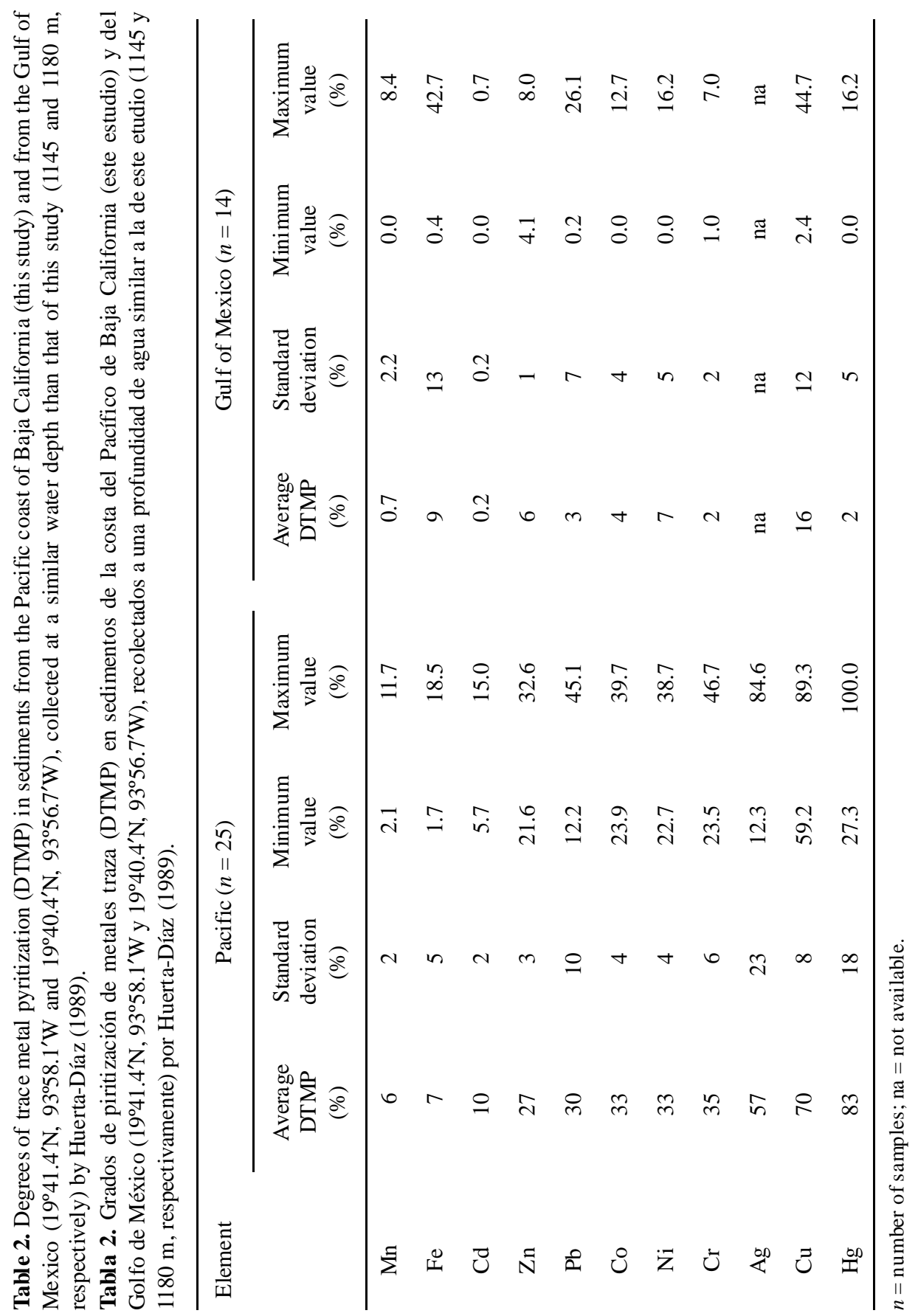


increasing rapidly in the next sample, and then remained approximately constant for the rest of the core, except for two points (fig. 4). $\mathrm{Hg}$ and $\mathrm{Pb}$ showed DTMP values going from about $25 \%$ to $100 \%$ and from $20 \%$ to $90 \%$, respectively, throughout the core. Finally, the order in which trace elements were pyritized was $\mathrm{Mn}<\mathrm{Fe}<\mathrm{Cd}<\mathrm{Zn}<\mathrm{Pb}<\mathrm{Co}<\mathrm{Ni}<\mathrm{Cr}<$ $\mathrm{Ag}<\mathrm{Cu}<\mathrm{Hg}$ (table 2).

\section{DISCUSSION}

Sediments from the core analyzed in this study are probably suboxic because of the observed lack of dissolved $\mathrm{H}_{2} \mathrm{~S}$ in their pore waters, the presence of AVS in the sediment, and the absence of measurable sulfate depletion with depth (average of $31.8 \pm 1.5 \mathrm{mM}$ of sulfate in the interstitial water along the core; unpublished data by the authors). Hence, pyrite production is probably low, as suggested also by its relatively slow increase in concentration with depth compared to the fast decrease in $\mathrm{Fe}-\mathrm{HCl}$ (fig. 2a). Furthermore, considering that the concentrations of AVS $\quad<0.003$ to $0.46 \mu \mathrm{mol} \mathrm{g}^{-1}$; fig. $2 \mathrm{~b}$ ) were well below the measured levels for Fe-pyrite along all the core, it is reasonable to assume that the transference of $\mathrm{Fe}$ is essentially towards pyrite formation (Howarth, 1978; Luther et al., 1982; Raiswell, 1982), or alternatively, that the transformation from $\mathrm{Fe}-\mathrm{AVS}$ to $\mathrm{Fe}$-pyrite is faster than the formation of AVS in these sediments. The increasing AVS concentration observed at the deepest part of the core could be due to higher concentrations of labile organic matter, which in turn can enhance the production of $\mathrm{H}_{2} \mathrm{~S}$, a process that may promote the transference of sulfur to AVS (Thode-Andersen and Jørgensen, 1989). However, the degree of association of some metals with pyrite can reach, in some cases, levels as high as $100 \%$ (e.g., $\mathrm{Hg}$; fig. $4 \mathrm{e}$ ), although there are other elements that
$\mathrm{Pb}>\mathrm{Ag}>\mathrm{Hg}$, mientras que en la fracción pirita el orden de abundancia fue $\mathrm{Fe}>\mathrm{Cu}>$ $\mathrm{Zn}>\mathrm{Ni}>\mathrm{Cr}>\mathrm{Mn}>\mathrm{Co}>\mathrm{Ag}>\mathrm{Pb}>\mathrm{Cd}>\mathrm{Hg}$. El uso de pruebas- $t$ o de pruebas de Suma de Rangos de Mann-Whitney (en caso de fallar la prueba de normalidad) dio diferencias significativas $(p<0.001)$ entre cada grupo de datos, lo que indica la existencia de diferencias reales entre las diversas concentraciones promedio de metales. El elemento más abundante en ambas fracciones fue el $\mathrm{Fe}$, mientras que $\mathrm{Mn} \mathrm{y} \mathrm{Cu}$ fueron los segundos elementos más abundantes en las fracciones $\mathrm{HCl}$ y pirita, respectivamente (tabla1).

Se observaron valores bajos relativamente constantes de DOP (alrededor de 2\%) durante los primeros $7 \mathrm{~cm}$ de profundidad y después éstos incrementaron gradualmente con la profundidad hasta cerca de $19 \%$ en el extremo final del núcleo (fig. 2b). Estos valores son bajos, en comparación con los niveles de hasta $40 \%$ de DOP en algunos sedimentos anóxico-sulfídico (Huerta-Díaz y Morse, 1992). Los resultados de DTMP muestran un incremento en la piritización con la profundidad para Mn y Ni, mientras que el Cd, Co y $\mathrm{Cr}$ mantuvieron valores relativamente constantes de DTMP a lo largo de todo el núcleo (fig.4). El Cu y $\mathrm{Zn}$ mostraron valores máximos a 5 y $9 \mathrm{~cm}$ de profundidad, respectivamente, mientras que los niveles de Ag disminuyeron durante los primeros $5 \mathrm{~cm}$, aumentando rápidamente en la siguiente muestra, y después permanecieron aproximadamente constantes en el resto del núcleo, excepto en dos puntos. El $\mathrm{Hg}$ y $\mathrm{Pb}$ mostraron valores de DTMP que iban de cerca de $25 \%$ a $100 \%$ y de $20 \%$ a $90 \%$, respectivamente, a lo largo de todo el núcleo. Finalmente, el orden en que los elementos traza fueron piritizados fue $\mathrm{Mn}<\mathrm{Fe}<$ $\mathrm{Cd}<\mathrm{Zn}<\mathrm{Pb}<\mathrm{Co}<\mathrm{Ni}<\mathrm{Cr}<\mathrm{Ag}<\mathrm{Cu}<\mathrm{Hg}$ (tabla 2). 

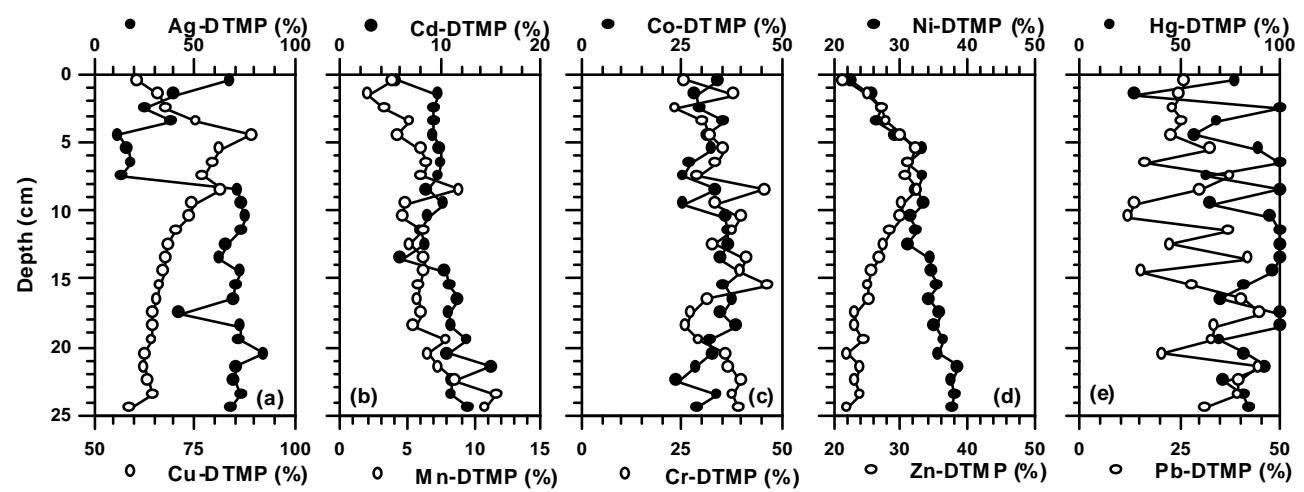

Figure 4. Degrees of trace metal pyritization as a function of sediment depth.

Figura 4. Grados de piritización de metales traza en función de la profundidad del sedimento.

have much lower DTMPs (e.g., Cd; fig. 4b). Despite the apparent variability in the degrees of pyritization, the elements analyzed can be grouped according to their different levels of association with pyrite, if average DTMP (and DOP) values are plotted against each metal, as shown in figure $5 \mathrm{a}$. Three groups can be readily distinguished: group 1 includes the extensively pyritized metals $\mathrm{Ag}, \mathrm{Cu}$ and $\mathrm{Hg}$, with average DTMP values in the range of $50-85 \%$; group 2 comprises those elements with intermediate DTMP levels (20-40\%), namely $\mathrm{Zn}, \mathrm{Pb}, \mathrm{Co}$, Ni and $\mathrm{Cr}$; and finally, group 3 includes $\mathrm{Mn}, \mathrm{Fe}$ and $\mathrm{Cd}$, which are very weakly pyritized $(<10 \%$ on average).

Our results indicate that a transference of $\mathrm{Cu}, \mathrm{Zn}$ and, to a certain extent, $\mathrm{Ni}, \mathrm{Hg}$ and $\mathrm{Ag}$, exists from the mineral phases dissolved in the $\mathrm{HCl}$ fraction (carbonates, $\mathrm{Fe}$ and $\mathrm{Mn}$ oxides, and AVS) to the pyrite phase, as indicated by the mirror-image shape of the $\mathrm{Me}-\mathrm{HCl}$ and $\mathrm{Me}$ pyrite profiles (figs. 2a, 3). The extent of this transference appears to be a function of two factors: the solubility products of metal sulfides and the relative abundances of metals in the $\mathrm{HCl}$ fraction. We plotted the average DTMP (and DOP) against their respective solubility product $\left(-\log \mathrm{K}_{\mathrm{sp}}\right.$, or $\left.\mathrm{pK}_{\mathrm{sp}}\right)$ of the different

\section{DISCUSIÓN}

Los sedimentos del núcleo analizado en este estudio probablemente son subóxicos, debido a la falta de $\mathrm{H}_{2} \mathrm{~S}$ disuelto en sus aguas intersticiales, la presencia de AVS en el sedimento y la ausencia de una disminución medible de sulfatos con la profundidad (31.8 \pm $1.5 \mathrm{mM}$, en promedio, de sulfatos en las aguas intersticiales a lo largo del núcleo; datos de los autores sin publicar). Por esta razón, la producción de pirita probablemente es baja, como también lo sugiere el lento incremento en su concentración con la profundidad, comparado con la rápida disminución en $\mathrm{Fe}-\mathrm{HCl}$ (fig. 2a). Además, tomando en consideración que las concentraciones de AVS $(<0.003$ a $0.46 \mu \mathrm{mol} \mathrm{g}^{-1}$; fig. $2 \mathrm{~b}$ ) estuvieron bastante por debajo de los niveles medidos de Fe-pirita a lo largo del núcleo, es razonable suponer que la transferencia de $\mathrm{Fe}$ es esencialmente hacia la formación de pirita (Howarth, 1978; Luther et al., 1982; Raiswell, 1982) o, dicho de otra manera, que la transformación de Fe-AVS a Fepirita en estos sedimentos es más rápida que la formación de AVS. La creciente concentración de AVS observada en la parte más profunda del núcleo pudo deberse a mayores concentracio- 
metals considered in this study $\left(\mathrm{K}_{\mathrm{sp}}\right.$ values for $\mathrm{Ag}$ and $\mathrm{Cr}$ sulfides are not available), and found a strong correlation $\left(r^{2}=0.853, n=9\right.$, $p<0.001$ ) with most of the points within the 95\% confidence level (dashed line in fig. 5b), suggesting the existence of an association between these two parameters. We selected values for the different $\mathrm{K}_{\mathrm{sp}}$ of sulfides and gave preference to minerals kinetically favored in marine sediments (e.g., amorphous FeS instead of $\mathrm{FeS}_{2}$; Morse and Casey, 1988), or those in the reduced state (e.g., $\mathrm{Cu}_{2} \mathrm{~S}$ instead of $\mathrm{CuS}$ ), considering that trace metals in oxic seawater exist dominantly as cations $\left(\mathrm{Hg}^{2+}, \mathrm{Cu}^{2+}\right.$ or ${ }^{3+}$, $\left.\mathrm{Co}^{2+}, \mathrm{Mn}^{2+}, \mathrm{Zn}^{2+}, \mathrm{Pb}^{2+}, \mathrm{Cd}^{2+}\right)$ or oxyanions $\left(\mathrm{AsO}_{4}{ }^{2-}, \mathrm{MoO}_{4}{ }^{2-}, \mathrm{CrO}_{4}{ }^{2-}\right)$, and that $\mathrm{As}(\mathrm{V})$, $\mathrm{Mo}(\mathrm{VI})$ and $\mathrm{Cr}(\mathrm{VI})$ must be reduced to As(III), $\mathrm{Mo}(\mathrm{IV})$ and $\mathrm{Cr}(\mathrm{III})$ prior to incorporation into sulfide minerals (Morse and Luther, 1999). Figure 6a shows the result of plotting the log of average concentrations in the pyrite fraction against the log of average concentrations in the $\mathrm{HCl}$ fraction for each element analyzed in our sediment core. The high correlation coefficient between these sediments $\left(r^{2}=0.904, n=11\right.$, $p<0.001)$ and the inclusion of most of the data plotted within the $95 \%$ confidence level of the linear regression curves (dashed line in fig. 6), suggest the existence of an association between these two fractions. Furthermore, this type of association $\left(r^{2}=0.702, n=12, p<0.001\right)$ is also observed in sediments from the southern part of the Gulf of Mexico (table 2), as shown in figure $6 \mathrm{~b}$, for two cores collected by Huerta-Díaz (1989). Hence, the higher the concentration of a given trace metal in the $\mathrm{HCl}$ fraction, the higher its concentration will be in the pyrite fraction. However, we do not observe the high linear correlations obtained in the log-log plots of figure 6 when data from shallower water sediments $(50,200$ and $500 \mathrm{~m})$ from the Gulf of Mexico (Huerta-Díaz, 1989) are plotted in a similar plot as figure 6 nes de materia orgánica lábil que, a su vez, puede potenciar la producción de $\mathrm{H}_{2} \mathrm{~S}$, un proceso que puede promover la transferencia de azufre a AVS (Thode-Andersen y \rgensen, 1989). Sin embargo, el grado de asociación de algunos metales con la pirita puede alcanzar, en algunos casos, niveles tan altos como el $100 \%$ (e.g., el $\mathrm{Hg}$; fig. 4e), aunque hay otros elementos que tienen DTMPs mucho menores (e.g., el Cd; fig. 4b). A pesar de la aparente variabilidad en los grados de piritización, los elementos analizados pueden ser agrupados de acuerdo con sus diferentes niveles de asociación con la pirita, si se grafican los valores promedio de DTMP (y DOP) contra cada metal, como se muestra en la figura 5a. Se pueden distinguir fácilmente tres grupos: el grupo 1 incluye los metales $\mathrm{Ag}, \mathrm{Cu}$ y $\mathrm{Hg}$, ampliamente piritizados con valores promedio de DTMP en el intervalo de $50 \%$ a $85 \%$; el grupo 2 comprende aquellos elementos con niveles intermedios de DTMP (20-40\%), a saber, $\mathrm{Zn}, \mathrm{Pb}, \mathrm{Co}, \mathrm{Ni}$ y $\mathrm{Cr}$; finalmente, el grupo3 incluye a $\mathrm{Mn}, \mathrm{Fe}$ y $\mathrm{Cd}$, que se encuentran muy débilmente piritizados (en promedio $<10 \%$ ).

Nuestros resultados indican que existe una transferencia de $\mathrm{Cu}, \mathrm{Zn}$ y, hasta cierto punto, de $\mathrm{Ni}, \mathrm{Hg}$ y Ag, de las fases minerales disueltas en la fracción $\mathrm{HCl}$ (carbonatos, óxidos de $\mathrm{Fe}$ y Mn, y AVS) a la fase pirítica, como lo indican las formas de imagen en espejo de los perfiles de $\mathrm{Me}-\mathrm{HCl}$ y Me-pirita (figs. 2a, 3). La magnitud de esta transferencia parece estar en función de dos factores: los productos de solubilidad de los sulfuros metálicos y las abundancias relativas de los metales en la fracción $\mathrm{HCl}$. Se graficaron los DTMP promedio (y DOP) contra su respectivo producto de solubilidad $\left(-\log \mathrm{K}_{\mathrm{ps}}\right.$, o pK $\left.\mathrm{ps}_{\mathrm{ps}}\right)$ de los diferentes metales considerados en este estudio (los valores del $\mathrm{K}_{\mathrm{ps}}$ para los sulfuros de Ag y Cr no están disponibles), y se encontró una fuerte correlación $\left(r^{2}=0.853, n=9, p<0.001\right)$ con la mayoría de los puntos dentro del intervalo de confianza del 

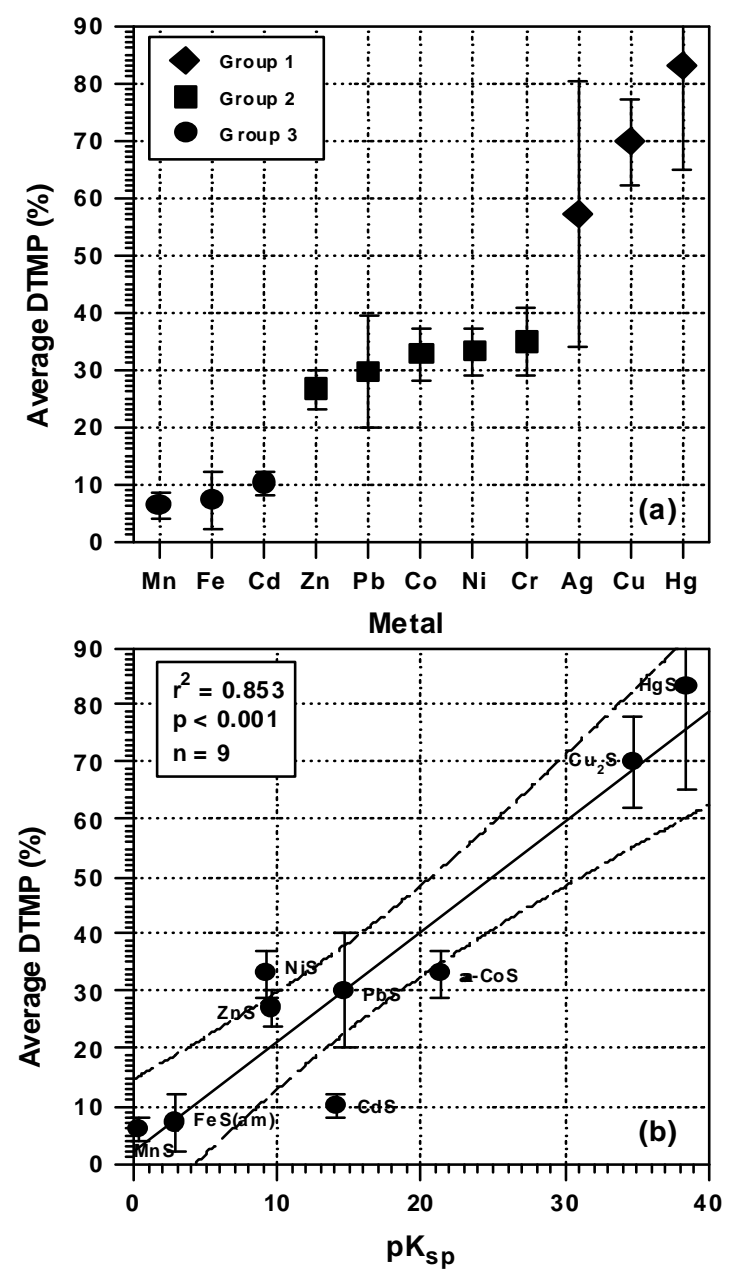

Figure 5. (a) Average degrees of pyritization as a function of the trace metals analyzed (see text for explanation of each group). (b) Average degrees of pyritization plotted against the solubility products of their metal sulfides (-log $\mathrm{pK}_{\mathrm{sp}}$ or $\mathrm{pK}_{\mathrm{sp}}$ ), taken from Emerson et al. (1983), Morse et al. (1987) and Di Toro et al. (1990). The metal sulfides considered included alabandite (MnS), amorphous iron sulfide $(\mathrm{FeS}(\mathrm{am}))$, millerite $(\mathrm{NiS})$, wurtzite $(\mathrm{ZnS})$, greenockite $(\mathrm{CdS})$, galena $(\mathrm{PbS}), \alpha-\mathrm{CoS}$, chalcocite $\left(\mathrm{Cu}_{2} \mathrm{~S}\right)$, and cinnabar $(\mathrm{HgS})$. Linear regression analysis and its $95 \%$ confidence level are represented by the continuous and dashed lines, respectively. Error bars represent one standard deviation.

Figura 5. (a) Grados de piritización promedio en función de los metales traza analizados (ver el texto para la explicación de cada grupo). (b) Grados de piritización promedio graficados contra los productos de solubilidad de sus sulfuros metálicos $\left(-\log \mathrm{pK}_{\mathrm{ps}}\right.$ o $\left.\mathrm{pK}_{\mathrm{ps}}\right)$, tomados de Emerson et al. (1983), Morse et al. (1987) y Di Toro et al. (1990). Los sulfuros considerados incluyeron alabandita (MnS), sulfuro de hierro amorfo $(\mathrm{FeS}(\mathrm{am}))$, milerita $(\mathrm{NiS})$, wurtzita $(\mathrm{ZnS})$, greenoquita $(\mathrm{CdS})$, galena $(\mathrm{PbS}), \alpha-\mathrm{CoS}$, calcocita $\left(\mathrm{Cu}_{2} \mathrm{~S}\right)$ y cinabrio $(\mathrm{HgS})$. El análisis de regresión lineal y su intervalo de confianza del $95 \%$ se representan por las líneas continua y puntuada, respectivamente. Las barras de error representan una desviación estándar. 

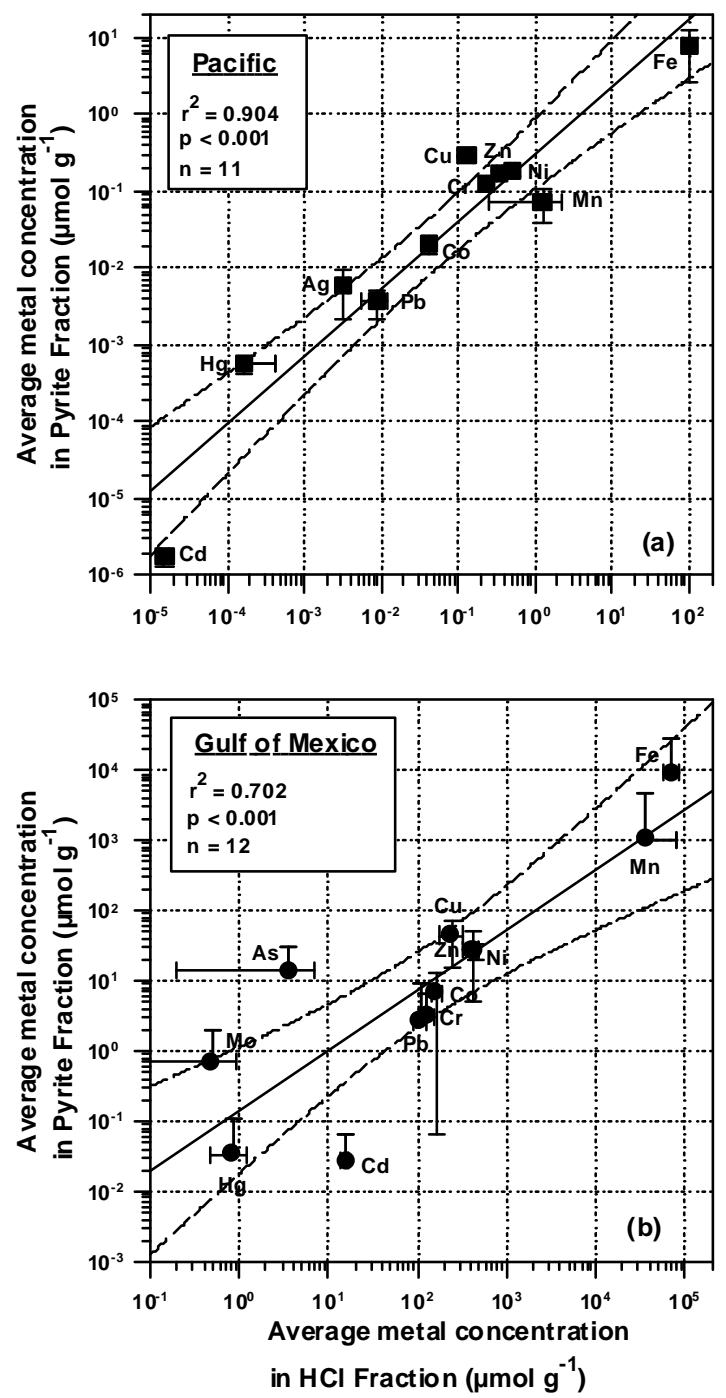

Figure 6. Average trace metal concentrations in the $\mathrm{HCl}$ fraction plotted against average trace metal concentrations in the pyrite fraction of (a) this study and (b) Gulf of Mexico sediments (data taken from Huerta-Díaz and Morse, 1992). Log-log linear regression analysis and its 95\% confidence level are represented by the continuous and dashed lines, respectively. Error bars represent one standard deviation. Figura 6. Concentraciones promedio de metales traza en la fracción $\mathrm{HCl}$ graficadas contra las concentraciones promedio de metales traza en la fracción pirita (a) de este estudio y (b) en sedimentos del Golfo de México (datos tomados de Huerta-Díaz y Morse, 1992). El análisis de regresión lineal logaritmo-logaritmo y su intervalo de confianza del 95\% están representados por las líneas continua y punteada, respectivamente. Las barras de error representan una desviación estándar. 
Ciencias Marinas, Vol. 27, No. 2, 2001

(data not shown). A possible explanation for this behavior may be a difference related to shallow $v s$ deep water environments. From a diagenetic point of view, the deeper the sediment, the closer it is to a closed system due to its lower sedimentation rate, lower reactive organic matter content and lower benthic activity, all of which tend to restrict the flow of chemical constituents among neighboring layers (Goldhaber and Kaplan, 1974; Thode, 1991). Additionally, the distribution of metals found in sedimentary pyrite can only be explained using both thermodynamic and kinetic approaches. It has been postulated that metals (e.g., $\mathrm{Pb}, \mathrm{Zn}$ and $\mathrm{Cd}$ ) that have faster water exchange reaction kinetics than $\mathrm{Fe}^{2+}$ are not significantly pyritized because they tend to form discrete sulfide mineral phases (MeS) prior to $\mathrm{FeS}$ formation and subsequent pyrite formation (Morse and Luther, 1999). Conversely, metals that have slower reaction kinetics than $\mathrm{Fe}^{2+}$ are incorporated into pyrite. Reactions that are important in shallower sediments due to their higher diagenetic and bioturbation activity (e.g., AVS formation, pyrite oxidation) may not be important in deeper, suboxic sediments where pyrite formation is slow and AVS concentrations tend to be low. For example, $\mathrm{Mn}^{2+}$ does not form a $\mathrm{MnS}$ phase easily, but it may be incorporated into pyrite in shallow, organic-rich sediments where high DOP levels can be reached (Morse and Luther, 1999). However, Mn may be preferentially incorporated into carbonate phases in deeper sediments where carbonate precipitation processes are more important, as may be the case for the samples from the Pacific continental borderland studied here.

\section{CONCLUSIONS}

Sediments from the Pacific coast of Baja California are not pyritized to a great extent
95\% (línea punteada de la fig. 5b), lo que sugiere la existencia de una asociación entre ambos parámetros. Se seleccionaron valores para los diferentes $\mathrm{K}_{\mathrm{ps}}$ de los sulfuros y se dio preferencia a los minerales cinéticamente favorecidos en los sedimentos marinos (e.g., FeS amorfo en lugar de $\mathrm{FeS}_{2}$; Morse y Casey, 1988) o los que se encuentran en estado reducido (e.g., $\mathrm{Cu}_{2} \mathrm{~S}$ en lugar de $\mathrm{CuS}$ ), considerando que los metales traza en el agua de mar óxica predominan como cationes $\left(\mathrm{Hg}^{2+}, \mathrm{Cu}^{2+}\right.$ o ${ }^{3+}, \mathrm{Co}^{2+}$, $\left.\mathrm{Mn}^{2+}, \mathrm{Zn}^{2+}, \mathrm{Pb}^{2+}, \mathrm{Cd}^{2+}\right)$ u oxianiones $\left(\mathrm{AsO}_{4}{ }^{2-}\right.$, $\left.\mathrm{MoO}_{4}{ }^{2-}, \mathrm{CrO}_{4}{ }^{2-}\right)$, y que $\mathrm{As}(\mathrm{V}), \mathrm{Mo}(\mathrm{VI})$ y $\mathrm{Cr}(\mathrm{VI})$ se deben reducir a As(III), Mo(IV) y $\mathrm{Cr}$ (III) antes de incorporarse a los minerales sulfurosos (Morse y Luther, 1999). La figura 6a muestra el resultado de graficar el logaritmo de las concentraciones promedio en la fracción pirita contra el logaritmo de las concentraciones promedio de la fracción $\mathrm{HCl}$ para cada elemento analizado en el núcleo de sedimentos. El elevado coeficiente de correlación entre estos sedimentos $\left(r^{2}=0.904, n=11, p<0.001\right)$ y la incidencia de la mayoría de los datos graficados dentro del intervalo de confianza del $95 \%$ de las curvas de regresión lineal (línea punteada de la fig. 6) sugieren la existencia de una asociación entre estas dos fracciones. Además, este tipo de asociación $\left(r^{2}=0.702, n=12\right.$, $p<0.001)$ también se observa en sedimentos de la parte sur del Golfo de México (tabla 2), como se muestra en la figura $6 \mathrm{~b}$, para dos núcleos recolectados por Huerta-Díaz (1989). Por lo tanto, mientras mayor sea la concentración de un determinado metal traza en la fracción $\mathrm{HCl}$, mayor será su concentración en la fracción pirita. Sin embargo, en las gráficas logaritmo-logaritmo de la figura 6 no se observan las elevadas correlaciones lineales observadas cuando se trazan los datos de sedimentos de aguas más someras $(50,200$ y $500 \mathrm{~m}$ ) del Golfo de México (Huerta-Díaz, 1989) en una gráfica similar a la figura 6 (datos no mostrados). Una 
(average of $7.2 \pm 4.9 \%$, with a maximum of $18.5 \%$ ), and have a low value compared with DOP levels of up to $40 \%$ in some anoxicsulfidic coastal sediments from the Gulf of Mexico (Huerta-Díaz and Morse, 1992). The extent of pyritization of the rest of the trace metals, however, was generally high, with average DTMP values that ranged from $6.2 \pm 2.1 \%$ to $83 \pm 18 \%$ for $\mathrm{Mn}$ and $\mathrm{Hg}$, respectively. This transference of trace metals from mineral phases like $\mathrm{Mn}$ and Fe oxides to pyrite apparently is a function of the solubility products of metal sulfides, the thermodynamics and kinetics of mineral formation in shallow $v s$ deep sediments, as well as the relative abundances of metals in the $\mathrm{HCl}$ fraction. The relationships found between these two parameters and the DTMP values are apparently more evident in suboxic (anoxic-nonsulfidic) sediments than in the more diagenetically-active sediments closer to the coastal zone. This difference may be due to the near-closed system characteristics of deep sediments that allow a more effective scavenging of metals by diagenetic pyrite, as well as to the relative importance of certain mineral-forming reactions (e.g., carbonate and AVS precipitation) in this type of marine environments.

\section{ACKNOWLEDGEMENTS}

The authors would like to thank S.P. Verma and A. Martín Barajas for offering comments that substantially improved the content of this work. Collection of the samples was possible due to the ship-handling skills of the crew of the $\mathrm{R} / \mathrm{V}$ Francisco de Ulloa during the METOX 2 cruise. The first author benefited from a scholarship from Consejo Nacional de Ciencia y Tecnología (CONACYT). This research was funded by CONACYT grant 431100-5-4958T to the second author. posible explicación para este comportamiento puede ser debido a una diferencia entre los ambientes de aguas someras y los de aguas profundas. Desde un punto de vista diagenético, mientras más profundo sea el sedimento, más cerca se encuentra de un sistema cerrado debido a su menor tasa de sedimentación, menor contenido de materia orgánica reactiva y menor actividad bentónica, todo lo cual tiende a restringir el flujo de constituyentes químicos entre capas vecinas (Goldhaber y Kaplan, 1974; Thode, 1991). Adicionalmente, la distribución de los metales encontrados en la pirita sedimentaria sólo puede ser explicada por medio de aproximaciones tanto termodinámicas como cinéticas. Se ha postulado que los metales (e.g., $\mathrm{Pb}, \mathrm{Zn}$ y $\mathrm{Cd}$ ) que tienen una cinética de reacción de intercambio de agua más rápida que el $\mathrm{Fe}^{2+}$ no se piritizan significativamente porque tienden a formar fases minerales sulfurosas discretas (MeS) antes de formar $\mathrm{FeS}$ $\mathrm{y}$, subsecuentemente, pirita (Morse y Luther, 1999). Por lo contrario, los metales que tienen cinéticas de reacción más lentas que el $\mathrm{Fe}^{2+}$ se incorporan a la pirita. Las reacciones importantes en sedimentos más someros debido a la mayor actividad diagenética y bioturbación (e.g., formación de AVS, oxidación de pirita) pueden no ser importantes en sedimentos subóxicos más profundos, donde la formación de pirita es lenta y las concentraciones de AVS tienden a ser bajas. Por ejemplo, el $\mathrm{Mn}^{2+}$ no forma fácilmente la fase $\mathrm{MnS}$, pero se puede incorporar a la pirita en sedimentos someros, ricos en materia orgánica, donde se pueden alcanzar elevados niveles de DOP (Morse y Luther, 1999). Sin embargo, el Mn puede ser incorporado preferentemente a las fases carbonatadas de los sedimentos más profundos, donde los procesos de precipitación de carbonatos son más importantes. Éste podría ser el caso de las muestras del margen continental del Pacífico aquí estudiadas. 
Ciencias Marinas, Vol. 27, No. 2, 2001

\section{REFERENCES}

Berner, R.A. (1970). Sedimentary pyrite formation. Am. J. Sci., 268: 1-23.

Berner, R.A. (1981). Authigenic mineral formation resulting from organic matter decomposition in modern sediments. Fortsch. Miner., 59: 117-135.

Berner, R.A. (1984). Sedimentary pyrite formation: An update. Geochim. Cosmochim. Acta, 48: 605-615.

Bertine, K.K. and Goldberg, E.D. (1977). History of heavy metal pollution in Southern California coastal zone - reprise. Environ. Sci. Technol., 11: 297-299.

Bruland, K.W., Bertine, K., Koide, M. and Goldberg, E.D. (1974). History of metal pollution in Southern California coastal zone. Environ. Sci. Technol., 8: 425-432.

Bruland, K.W., Franks, R.P., Knauer, G.A. and Martin, J.H. (1979). Sampling and analytical methods for the nanogram per liter determination of copper, cadmium, zinc and nickel in seawater. Anal. Chim. Acta, 105: 233-241.

Chow, T.J., Bruland, K.W., Bertine, K.K., Soutar, A., Koide, M. and Goldberg, E.D. (1973). Lead pollution: Records in Southern California coastal sediments. Science, 181: 551-552.

Cline, J.D. (1969). Spectrophotometric determination of hydrogen sulfide in natural waters. Limnol. Oceanogr., 14: 454-458.

Cornwell, J.C. and Morse, J.W. (1987). The characterization of iron sulfide minerals in marine sediments. Mar. Chem., 22: 193-206.

Di Toro, D.M., Mahony, J.D., Hansen, D.J., Scott, K.J., Hicks, M.B., Mayr, S.M. and Redmond, M.S. (1990). Toxicity of cadmium in sediments: The role of acid volatile sulfide. Environ. Toxicol. Chem., 9: 1487-1502.

Emerson, S., Jacobs, L. and Tebo, B. (1983). The behavior of trace metals in marine anoxic waters: Solubilities at the oxygen-hydrogen sulfide interface. In: C.S. Wong, E. Boyle, K.W. Bruland, J.D. Burton and E.D. Goldberg (eds.), Trace Metals in Sea Water. Plenum Press, New York, pp. 579-608.

\section{CONCLUSIONES}

Los sedimentos de la costa del Pacífico de Baja California no se encuentran ampliamente piritizados $(7.2 \pm 4.9 \%$ en promedio, con un máximo de $18.5 \%$ ) y tienen un valor bajo de DOP, comparado con los niveles de hasta $40 \%$ en algunos sedimentos anóxico-sulfídico costeros del Golfo de México (Huerta-Díaz y Morse, 1992). No obstante, la magnitud de la piritización del resto de los metales traza fue generalmente mayor, con valores promedio de DTMP que variaron desde $6.2 \pm 2.1 \%$ a $83 \pm 18 \%$ para el $\mathrm{Mn}$ y el $\mathrm{Hg}$, respectivamente. Esta transferencia de metales traza de fases minerales como los óxidos de $\mathrm{Mn}$ y $\mathrm{Fe}$ a pirita aparentemente está en función de los productos de solubilidad de los sulfuros metálicos, de la termodinámica y cinética de la formación de minerales en sedimentos someros contra las de los sedimentos profundos, así como de las abundancias relativas de los metales en la fracción $\mathrm{HCl}$. Las relaciones encontradas entre estos dos parámetros y los valores de DTMP aparentemente son más evidentes en sedimentos subóxicos (anóxicos no sulfurosos) que en sedimentos diagenéticamente más activos cercanos a la zona costera. Esta diferencia se puede deber a las características de un sistema casi cerrado como los sedimentos profundos, que permiten una remoción más efectiva de los metales por la pirita diagenética, así como a la importancia relativa de ciertas reacciones de formación de minerales (e.g., precipitación de carbonatos y AVS) en este tipo de ambientes marinos.

\section{AGRADECIMIENTOS}

Los autores agradecen a S.P. Verma y a A. Martín Barajas sus comentarios que mejoraron sustancialmente el contenido de este trabajo. La recolección de muestras fue posible gracias a la dedicación de la tripulación del 
François, R. (1988). A study on the regulation of theconcentrations of some trace metals $(\mathrm{Rb}, \mathrm{Sr}$, $\mathrm{Zn}, \mathrm{Pb}, \mathrm{Cu}, \mathrm{V}, \mathrm{Cr}, \mathrm{Ni}, \mathrm{Mn}$, and $\mathrm{Mo}$ ) in Saanich Inlet, British Columbia, Canada. Mar. Geol., 83: 285-308.

Goldhaber, M.B. and Kaplan, I.R. (1974). The sulfur cycle. In: E.D. Goldberg (ed.), The Sea. Wiley Interscience, New York, Vol. 5, pp.569-655.

Howarth, R.W. (1978). A rapid and precise method for determining sulfate in seawater, estuarine waters, and sediment pore waters. Limnol. Oceanogr., 23: 1066-1069.

Huerta-Díaz, M.A. (1989). Geochemistry of trace metals associated with sedimentary pyrite from anoxic marine environments. Ph.D. thesis, Texas A\&M University, $299 \mathrm{pp}$.

Huerta-Díaz, M.A. and Morse, J.W. (1990). A quantitative method for determination of trace metal concentrations in sedimentary pyrite. Mar.Chem., 29: 119-144.

Huerta-Díaz, M.A. and Morse, J.W. (1992). Pyritization of trace metals in anoxic marine sediments. Geochim. Cosmochim. Acta, 56: 2681-2702.

Huh, C.A., Finney, B.P. and Stull, J.K. (1992). Anthropogenic inputs of several heavy metals to nearshore basins off Los Angeles. Prog. Oceanogr., 30: 335-351.

Luther, G.W., III, Giblin, A., Howarth, R.W. and Ryans, R.A. (1982). Pyrite and oxidized iron mineral phases formed from pyrite oxidation in salt marsh and estuarine sediments. Geochim. Cosmochim. Acta, 46: 2665-2669.

Morford, J.L. and Emerson, S. (1999). The geochemistry of redox sensitive trace metals in sediments. Geochim. Cosmochim. Acta, 63: 1735-1750.

Morse, J.W. and Casey, W.H. (1988). Ostwald processes and mineral paragenesis in sediments. Am. J. Sci., 288: 537-560.

Morse, J.W. and Luther, G.W., III (1999). Chemical influences on trace metal-sulfide interactions in anoxic sediments. Geochim. Cosmochim. Acta, 63: 3373-3378.
B/I Francisco de Ulloa en el crucero oceanográfico METOX 2. El primer autor recibió el apoyo de una beca del Consejo Nacional de Ciencia y Tecnología (CONACYT). Esta investigación fue financiada por CONACYT, proyecto 431100-5-4958T otorgada al segundo autor.

Traducido al español por Manuel Gardea.

Morse, J.W., Millero, F.J., Cornwell, J.C. and Rickard, D. (1987). The chemistry of hydrogen sulfide and iron sulfide systems in natural waters. Earth Sci. Rev., 24: 1-42.

Raiswell, R. (1982). Pyrite texture isotopic composition and the availability of iron. Am. J. Sci., 282: 1244-1263.

Rickard, D., Schoonen, M.A.A. and Luther, G.W., III (1995). Chemistry of iron sulfides in sedimentary environments. ACS Symp. Ser., 612: 168-193.

Schiff, K.C. (2000). Sediment chemistry on the mainland shelf of the Southern California Bight. Mar. Pollut. Bull., 40: 268-276.

Thode, H.G. (1991). Sulfur isotopes in nature and the environment: An overview. In: H.R. Krouse and V.A. Grinenko (eds.), Stable Isotopes: Natural and Anthropogenic Sulphur in the Environment. Scope 43. John Wiley, New York, pp. 1-26.

Thode-Andersen, S. and Jørgensen, B.B. (1989). Sulfate reduction and the formation of ${ }^{35} \mathrm{~S}$ labelled $\mathrm{FeS}, \mathrm{FeS}_{2}$, and $\mathrm{S}^{\mathrm{o}}$ in coastal marine sediments. Limnol. Oceanogr., 34: 793-806.

Villaescusa-Celaya, J.A., Gutiérrez-Galindo, E.A. and Flores-Muñoz, G. (1997). Heavy metals in geochemical sediment fractions of the border region between Baja California, Mexico, and California, USA. Ciencias Marinas, 23: 43-70.

Villaescusa-Celaya, J.A., Gutiérrez-Galindo, E.A. and Flores-Muñoz, G. (2000). Heavy metals in the fine fraction of coastal sediments from Baja California (Mexico) and California (USA). Environ. Pollut., 108: 453-462. 